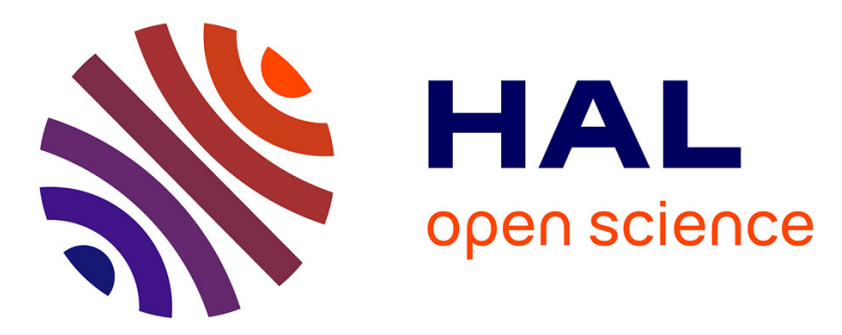

\title{
Evolution of diversity of fruits and vegetables crops
}

\author{
Michel Pitrat, Jean Marc Audergon
}

\section{To cite this version:}

Michel Pitrat, Jean Marc Audergon. Evolution of diversity of fruits and vegetables crops. 2. Symposium on Horticulture in Europe, Jul 2012, ANGERS, France. hal-02746535

\section{HAL Id: hal-02746535 \\ https://hal.inrae.fr/hal-02746535}

Submitted on 3 Jun 2020

HAL is a multi-disciplinary open access archive for the deposit and dissemination of scientific research documents, whether they are published or not. The documents may come from teaching and research institutions in France or abroad, or from public or private research centers.
L'archive ouverte pluridisciplinaire HAL, est destinée au dépôt et à la diffusion de documents scientifiques de niveau recherche, publiés ou non, émanant des établissements d'enseignement et de recherche français ou étrangers, des laboratoires publics ou privés. 


\section{SHE 2012}

IS ORGANISED BY AGROCAMPUS OUEST

UNDER THE AEGIS OF ISHS

AND THE NATIONAL EUROPEAN HORTICULTURAL SOCIETIES

\section{BOOK OF ABSTRACTS}

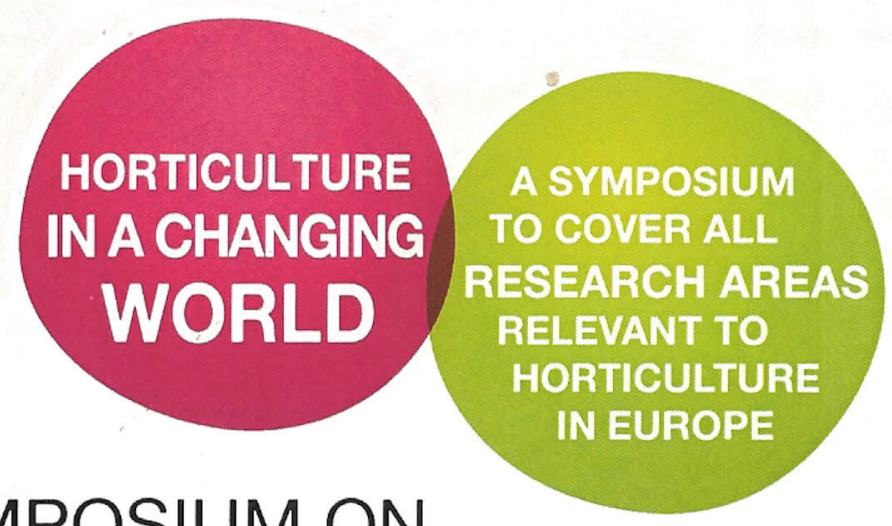

$2^{N D}$ SYMPOSIUM ON

HORTICULTURE IN EUROPE ANGERS, FRANCE $1^{\text {ST }}$ - 5 JULY 2012

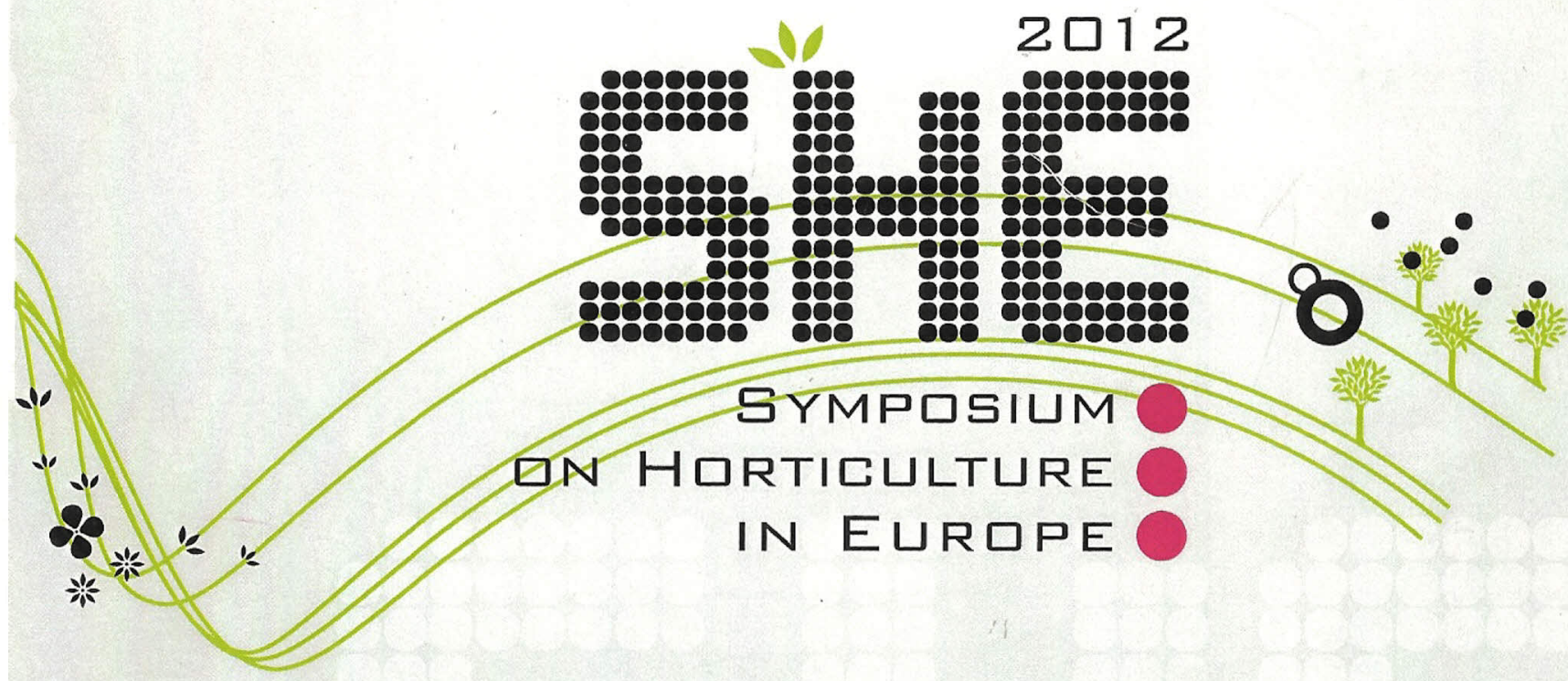




\title{
Evolution of diversity of fruits and vegetables crops
}

\author{
PITRAT, M. \& AUDERGON, J.M. \\ INRA UR1052, Génétique et Amélioration des Fruits et Légumes, Domaine Saint Maurice, BP 94, \\ 84143 Montfavet cedex (France)
}

We will answer only to a part of the session title (Horticulture and biodiversity: contribution to its loss, conservation or increase?) which includes the impact of the cultivars and cultivation methods on the biodiversity. Our presentation will focus on the diversity of fruits and vegetables crops in Europe at the species, cultigroup and cultivar levels and its evolution with time.

Due to climatic conditions and cultural traditions, only a part of the world fruit and vegetable diversity is cultivated in Europe. Until the Second World War, most of the cultivars were locally based. Since the 1950', major evolutions have affected most of the cultivated species at several levels:

1. An enlargement of the number of cultivated species, with the introduction for instance of kiwi (Actinidia), nashi (Pyrus pyrifolia) or Japanese plums (Prunus salicina). During the same time, some species have decreased even if they have not completely disappeared, for instance common salsify (Tragopogon porrifolius) or calabash (Lagenaria).

2. A second level is the "cultigroup" or "botanical variety" within a species. New cultigroups have been introduced or created introducing market segmentation. This phenotypic diversification can be illustrated for instance by:

- Galia type of melon, yellow-fleshed watermelon;

- red apricot, flat peach, bloody peach;

- seedless grape, seedless watermelon, parthenocarpic cucumber;

- red Belgian endive or red witloof, oak-leaf and "Lollo" lettuce;

- cherry tomato, long shelf life tomato.

The success of a new "cultigroup" is difficult to forecast, for instance white eggplants have since many years a low commercial impact.

On the opposite, some cultigroups have decreased: for instance winter radish as compared with summer radish,

3. The third level is the cultivar with a tremendous increase of the number of available cultivars. Within a cultigroup, many cultivars are created which differ by some characters which usually are not noticed by the consumers but are important for growers, for instance disease resistance, earliness or lateness for the enlargement of the period of production, adaptation to soil and climatic conditions. For some species, the lifetime of cultivars may be very short, for instance 2 to 5 years in lettuce. These cultivars differ by a small number of genes introduced from related or distant accessions or even from interspecific crosses followed by backcrosses.

Almost 20000 cultivars of vegetables are registered in the European catalog: 3320 for tomato, 1965 for lettuce, 1285 for French beans, 951 for onion, 866 for cucumber... Conservation varieties and varieties for gardeners are registered in special lists.

Diversity at this level, at least for the vegetable market, is high due to the activity of private seed companies. In many crops, open pollinated cultivars (lines or populations) have been replaced by F1 hybrids.

4. "Club strategies" for the development of new cultigroups or cultivars are on the rise. For instance Pink Lady® for the apple cultivar Cripps Pink.

This situation will probably continue in the next future, with the development of new cultigroups and then the release of many cultivars adding small touches around this central figure. Concerning the genotypic variation estimated by neutral molecular markers like microsatellites or SNPs, several situations have been described:

- The enlargement of the phenotypic variability is not clearly associated with the enlargement of the genotypic diversity as for peach.

- In the case of tomato, the cherry tomatoes are quite different from the large-fruited types and, within this group, it seems that two main sub-groups are emerging: cultivars for the fresh market and cultivars for processing.

- For apricot or grape, the genotypes of modern cultivars reflect an enlargement by introduction and introgression of foreign germplasm into local types.

On a larger scale, the structuration of the world genetic diversity is helpful for the conservation, the evaluation and the use in breeding programs of genetic resources. New prospects or concerns based onto climatic change potential impacts and production durability have to be addressed. Development of future cultivars requires the mobilization of new adapted germplams. The characterization of the world existing resources on both morphological and genotypic bases is of major importance 